\title{
STUDI PENAMBATAN MOLEKUL SENYAWA FLAVONOID DAUN TABAT BARITO (Ficus deltoidea Jack) DALAM MENGHAMBAT ENZIM TIROSINASE
}

\section{MOLECULAR DOCKING STUDY OF FLAVONOID COMPOUNDS IN TABAT BARITO LEAVES (Ficus deltoidea Jack) FOR INHIBITING TYROSINASE ENZYME}

\author{
Alfisyahriatunnida Meily ${ }^{1}$, Andika $^{1}$ \& Aris Purwanto ${ }^{1}$ \\ ${ }^{1}$ S1 Farmasi, Fakultas Farmasi, Universitas Muhammadiyah Banjarmasin \\ Jl. Gubernur Sarkawi, Handil Bakti, Kalimantan Selatan. \\ Email:needmeily16@gmail.com,+6281253455090
}

Submitted : 11 Juli $2021 \quad$ Reviewed : 30 Juli 2021 Accepted : 6 September 2021

\begin{abstract}
ABSTRAK
Hiperpigmentasi merupakan suatu keadaan di mana terjadinya sintesis melanin yang berlebihan dan mengakibatkan penggelapan warna kulit. Enzim tirosinase merupakan enzim dengan dua atom tembaga yang memiliki peranan penting dalam proses pembentukan melanin. Senyawa flavonoid dengan aktivitas antioksidannya dilaporkan dapat menghambat enzim tirosinase dengan cara mengkhelat atom tembaga pada sisi aktif enzim tersebut. Secara in vitro, daun tabat barito (Ficus deltoidea Jack) diketahui memiliki aktivitas sebagai antimelanogenik karena adanya aktivitas antioksidan yang kuat, akan tetapi belum diketahui senyawa mana yang mempunyai andil dalam proses tersebut. Penelitian ini bertujuan untuk mengetahui lebih spesifik tekait senyawa flavonoid yang terdapat dalam daun tabat barito yang berperan dalam penghambatan terhadap enzim tirosinase PDB ID: 2Y9X yang dilakukan secara in silico untuk menghemat waktu dan biaya dengan uji penambatan molekul menggunakan program AutoDock 4.2. Selain dilakukan penambatan, juga dilakukan prediksi karakteristik senyawa yang ditujukan secara khusus pada uji permeabilitas dan sensititas kulit. Hasil yang diperoleh menunjukkan bahwa terdapat beberapa senyawa yang menunjukkan penghambatan terhadap enzim tirosinase ditandai dengan rendahnya nilai energi bebas $(-\Delta \mathrm{G})$ yaitu vitexin dan catechin $-5.78 \mathrm{kcal} / \mathrm{mol}$, epicatechin $-5.54 \mathrm{kcal} / \mathrm{mol}$, orientin $-5.43 \mathrm{kcal} / \mathrm{mol}$, epiafzelechin $-5.38 \mathrm{kcal} / \mathrm{mol} \mathrm{dan}$ gallocatechin $-5.08 \mathrm{kcal} / \mathrm{mol}$. Dari sisi model pengikatan, terdapat beberapa senyawa yang berikatan langsung dengan atom tembaga yaitu vitexin, catechin, epicatechin, epiafzelechin, epigallocatechin dan orientin serta residu asam amino pada enzim yang banyak terlibat dalam pembentukan ikatan hidrogen adalah Asn 260, Arg 268, His 244, Gly 281, His 85, dan Ser 282.
\end{abstract}

Kata kunci: Penambatan Molekul, Flavonoid, Ficus deltoidea Jack, Inhibitor Tirosinase

\section{ABSTRACT}

Hyperpigmentation is a circumstance where excess melanin synthesis occurs and results in the suppression of skin color. The enzyme tyrosinase is an enzyme with two copper atoms 
that play a key role in the melanin formation process. A flavonoid with antioxidant activity is reported to have blocked the enzyme tyrosinase by chelating copper atoms on the enzyme's active site. In vitro study of tabat barito leaves (Ficus deltoidea Jack) is known to act as anti-melanogenic due to the strong antioxidant activity, but no known compound plays a part in the process. This study aims to determine more specifically the flavonoid compounds contained in tabat barito leaves that play a role in inhibiting the tyrosinase enzyme PDB ID: $2 Y 9 X$ which was carried out in silico to save time and cost by molecular docking tests using the AutoDock 4.2 program. Besides, there are also predictive characteristics of the compounds specifically assigned to permeable tests and skin sensitivity. The results indicated that some flavonoid compounds inhibiting tyrosinase enzyme are marked by their low incidence of free energy $(-\Delta G)$ and that of vitexin and catechin $-5.78 \mathrm{kcal} / \mathrm{mol}$, epicatechin $-5.43 \mathrm{kcal} / \mathrm{mol}$, epiafzelechin $-5.38 \mathrm{kcal} / \mathrm{mol}$, and gallocatechin $-5.08 \mathrm{kcal} / \mathrm{mol}$. From the side of the attachment model, there are several compounds attached directly to the copper atoms as vitexin, catechin, epicatechin, epigallocatechin, epigallocatechin, orientin, and the residue of amino acids in the enzymes that are primarily involved in the formation of hydrogen bonds such as Asn 260, Arg 268, His 244, Gly 281, His 85, and Ser 282.

Keywords: Molecular Docking, Flavonoid, Tabat Barito, Ficus deltoidea, Tyrosinase Inhibitor

\author{
Penulis Korespondensi : \\ Alfisyahriatunnida Meily \\ Universitas Muhammadiyah Banjarmasin \\ Jl. Gubernur Sarkawi, Handil Bakti, Kalimantan Selatan. \\ Email : needmeily16@gmail.com
}

\title{
PENDAHULUAN
}

Dewasa ini produk kosmetik dan skincare berkembang sangat pesat, salah satu jenis sediaan yang paling digemari para wanita adalah produk pencerah kulit, baik untuk wajah maupun badan. Menurut kebanyakan wanita Asia, mereka berasumsi bahwasanya orang yang memiliki kulit putih akan terlihat menjadi lebih muda dan cantik sehingga produk pencerah kulit begitu diminati serta terus berkembang di pasar kosmetik dan skincare (Arifianti, et al., 2017). Perubahan warna kulit yang menjadi lebih gelap salah satunya disebabkan karena efek samping dari paparan sinar matahari yang berlebih. Melanin berperan untuk melindungi kulit dari sinar ultraviolet (UV). Saat melanin diproduksi secara berlebihan maka dapat menyebabkan warna kulit berubah menjadi lebih gelap atau depigmentasi. Penghambatan enzim tirosinase untuk mencegah proses depigmentasi adalah salah satu cara yang paling banyak digunakan (Charissa, et al., 2017). Diketahui bahwa tirosinase adalah enzim utama untuk biosintesis melanin. Oleh karena itu, inhibitor tirosinase telah dilaporkan dan diuji sebagai agen terapi dalam pengobatan hiperpigmentasi melanin dan sebagai kosmetik untuk memutihkan setelah terbakar sinar matahari (Walters \& Roberts, 2008).

Tren "kembali ke alam" atau "back to nature" dalam beberapa tahun terakhir sangat diminati dan berkembang pesat terutama pada produk pemutih dari bahan alami (Ghafari, et al., 2017). Indonesia sebagai negara dengan hutan tropisnya serta memiliki beragam tanaman yang identik dan khas, dari keberagaman tersebutlah kemudian tanaman yang ada sangat berpotensi untuk diteliti dan dikembangkan lebih lanjut. Salah satu dari sekian banyak tanaman yang memiliki potensi tersebut adalah tabat barito (Ficus deltoidea Jack). Secara in vitro, ekstrak daun tabat barito diketahui mampu menghambat enzim tirosinase pada sel melanoma B16F1 (Oh, et al., 2011). Akan tetapi, belum diketahui senyawa apakah yang terdapat di dalam ekstrak tersebut yang berperan dalam penghambatan tirosinase. Sebelumnya telah dilaporkan bahwasanya beberapa senyawa flavonoid dapat menghambat aktivitas dari enzim tirosinase (Qian, et al., 2020). 
Penemuan dan pengembangan obat adalah proses yang sangat menantang sekaligus rumit karena membutuhkan waktu yang lama dan ada banyak faktor risiko yang dapat menyebabkan kegagalan. Menurut data yang dilaporkan dalam sebuah penelitian dan produsen farmasi, diketahui bahwa proses penemuan dan pengembangan obat baru hingga dapat dipasarkan membutuhkan biaya yang sangat mahal, dengan perkiraan sebanyak $\$ 880$ juta US dolar dan membutuhkan waktu hingga 14 tahun. Salah satu usaha untuk mengatasi permasalahan tersebut adalah dengan memprediksi senyawa aktif baik efikasinya maupun efek samping secara in silico (Aji, 2019; Wadood, et al., 2013). In silico merupakan sebuah metode pendekatan dari suatu kondisi atau keadaan yang nyata ke dalam simulasi komputer dengan menggunakan program tertentu yang kemudian dapat dimanfaatkan untuk mendesain obat, salah satunya adalah studi molecular docking atau biasa dikenal dengan penambatan molekul (Geldenhuys, et al., 2006). Studi penambatan molekul ialah sebuah studi yang mempelajari bagaimana dua atau lebih struktur molekul dapat berikatan secara tiga dimensi. Penambatan molekuler pada umumnya digunakan untuk memprediksi struktur kompleks intermolekular yang terbentuk antara dua atau lebih molekul dan salah satunya yang paling menarik adalah interaksi antara ligan dengan protein (Zuchiran, 2010). Oleh karena itu, penelitian ini dilakukan secara in silico menggunakan metode penambatan molekul dengan tujuan untuk mengetahui lebih spesifik terkait potensi senyawa flavonoid dari daun tabat barito dalam menghambat enzim tirosinase serta bagaimana interaksinya pada tingkat molekuler.

\section{METODE PENELITIAN}

\section{Alat dan Bahan}

Alat yang digunakan untuk uji in silico adalah laptop dengan prosesor Intel ${ }^{\circledR}$ Core ${ }^{\mathrm{TM}}$ i5-10210U dengan RAM 8 GB dilengkapi sistem operasi Windows 1064 bit. Adapun program untuk docking molecular adalah AutoDock 4.2, Avogadro, Discovery Studio Visualizer, Open Babel, PyMOL, dan LigPlot. Selain itu terdapat aplikasi penunjang lain yaitu Notepad++.

Bahan yang digunakan untuk penentuan aktivitas senyawa flavonoid terhadap enzim tirosinase secara in silico adalah enzim tirosinase yang diekstraksi dari organisme Agaricus bisporus diunduh dari http://www.rcsb.org/pdb/home/home.do dengan PDB ID: 2Y9X dan tropolone sebagai native ligand. Senyawa kojic acid digunakan sebagai pembanding dan senyawa uji yang berupa senyawa flavonoid dari daun tabat barito (Ficus deltoidea Jack) didapatkan dari penelitiaan yang dilakukan oleh (Nurmaida et al., 2018; Omar et al., 2011) dan dipilih 13 senyawa flavonoid yang terdapat pada daunnya saja kemudian senyawa tersebut diunduh dari situs PubChem yang dapat diakses melalui link https://pubchem.ncbi.nlm.nih.gov/.

\section{Jalannya Penelitian}

1. Preparasi protein kristalisasi

Preparasi protein kristalisasi dilakukan untuk memisahkan reseptor dan native ligand sekaligus dilakukan juga penghapusan molekul air serta penambahan atom hidrogen dengan menggunakan aplikasi Discovery Studio Visualizer

2. Minimisasi energi

Selanjutnya pada senyawa uji, pembanding dan native ligand dilakukan proses minimisasi dengan menggunakan aplikasi Avogadro dengan parameter MMFF94. Adapun untuk reseptor diminimisasi menggunakan aplikasi Swiss PDB Viewer dengan parameter GORMOS96.

3. Validasi metode

Validasi metode molecular docking dilakukan dengan cara menambatkan kembali (redocking) native ligand pada protein target menggunakan program AutoDock Tools 4.2. Setting grid box sangat diperlukan pada tahap ini dengan tujuan untuk mengetahui sisi aktif 
dari reseptor yang kemudian dapat digunakan sebagai acuan ketika melakukan penambatan pada senyawa uji.

4. Penambatan molekul

Senyawa uji yang telah telah dilakukan minimisasi energi kemudian ditambatkan pada reseptornya yaitu tirosinase menggunakan program AutoDock Tools 4.2. Luaran hasil dari dilakukannya penambatan adalah berupa pose dan score.

5. Identifikasi dan visualisasi interaksi

Identifikasi interaksi ikatan hydrogen ligan-reseptor yang telah diisolasi dari konformasi terbaik secara dua dimensi dilakukan dengan menggunakan aplikasi LigPlot+ sedangkan untuk visualisasi secara tiga dimensi menggunakan aplikasi PyMOL.

6. Prediksi karakteristik senyawa

Prediksi karakteristik senyawa atau screening ADMET ditujukan khusus pada permeabilitas dan sensisitas kulit yang dilakukan melalui situs PkCSM pada link berikut http://biosig.unimelb.edu.au/PkCSM/prediction. Untuk melakukan uji ADMET pada PkCSM sebelumnya, format senyawa uji terlebih dahulu harus dikonversi ke dalam bentuk SMILES menggunakan aplikasi Open Babel.

\section{HASIL DAN PEMBAHASAN}

Simulasi penambatan molekul ini bertujuan untuk mengetahui adanya potensi serta bagaimana interaksi senyawa flavonoid pada daun tabat barito dalam menghambat enzim tirosinase pada tingkat molekuler menggunakan program AutoDock Tools. Program AutoDock lebih unik karena merupakan satu-satunya program docking yang banyak digunakan dan dirilis di bawah lisensi open source, program ini juga tersedia secara gratis untuk penggunaan akademis dan industry (Chang, et al., 2010). Protein kristalisasi yang ditentukan untuk melakukan studi penambatan molekul ini adalah struktur tiga dimensi enzim tirosinase yang diekstraksi dari organisme Agaricus bisporus atau jamur kancing dengan PDB ID: 2Y9X yang memiliki senyawa tropolone sebagai inhibitor dan berguna sebagai penuntun pada pembentukan sisi aktif enzimnya.

Preparasi protein kristalisasi enzim tirosinase dilakukan untuk memisahkan native ligand dari reseptor, serta dilakukan penghapusan molekul air yang betujuan agar molekul air tidak mengganggu pada saat proses docking, dan dilakukan penambahan atom hidrogen dengan tujuan untuk menyesuaikan suasana docking agar mendekati suasana $\mathrm{pH}$ di dalam tubuh (Widyastuti, et al., 2020) dan untuk memunculkan kembali atom hidrogen pada makromolekul agar dapat mengamati interaksi ikatan hidrogen yang terbentuk (Madhavi Sastry, et al., 2013). Enzim tirosinase dengan PDB ID: 2Y9X memiliki 4 rantai yaitu rantai A, B, C dan D (Ismaya, et al., 2011), dan untuk proses simulasi hanya dipilih salah satu dari keempat rantai tersebut agar pemilihan sisi aktif dari protein target menjadi lebih fokus pada satu rantai saja.

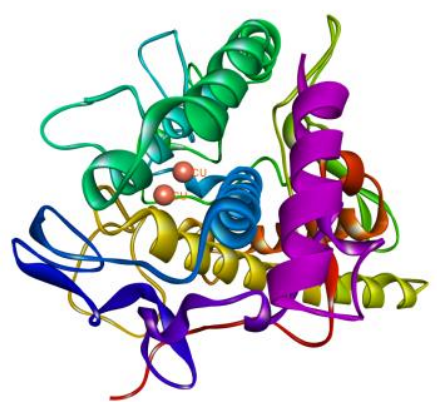

(a)

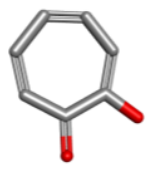

(b)

Gambar 1. (a) Protein kristalisasi 2Y9X rantai B (b) native ligand tropolone

Setelah dilakukan pemisahan, selanjutnya yaitu dilakukan proses minimisasi energi. Hasil dari proses ini ditunjukkan dengan terjadinya penurunan energi total senyawa. Nilai 
energi hasil minimisasi yang semakin rendah menandakan bahwa senyawa tersebut memiliki interaksi yaitu berupa gaya tarik antar atom semakin besar dan sebaliknya gaya tolak antar atom semakin kecil sehingga menyebabkan konformasi senyawa yang diperoleh menjadi semakin stabil (Widyastuti, et al., 2020).

Sebelum simulasi terlebih dahulu dilakukan validasi metode sebagai pengujian akurasi metode docking (Silva, et al., 2017). Hal yang paling utama yang harus dilakukan saat validasi metode molecular docking adalah pengaturan grid box. Penentuan grid box perlu dilakukan untuk mengetahui titik koordinat pada binding site dari suatu protein sehingga dapat menjadi acuan saat melaukukan proses simulasi docking senyawa uji pada nantinya. Parameter diterimanya validasi metode ditunjukkan dengan nilai RMSD (Root Mean Square Deviation) < 2.0 Amstrong (Yanuar, 2012). Berdasarkan hasil redocking didapatkan nilai RMSD 1,97 pada rantai B yang menandakan bahwa metode yang digunakan dapat dikatakan valid sehingga proses docking senyawa uji yang berupa senyawa flavonoid dari daun tabat barito dapat dilakukan.

Senyawa uji yang telah telah dilakukan minimisasi energi kemudian ditambatkan pada tirosinase menggunakan program AutoDock Tools. Dalam proses docking senyawa uji, digunakan ukuran grid box dan koordinat yang diperoleh saat validasi metode yaitu ukuran $40 \times 40 \times 40 \AA$ dengan space $0.375 \AA$ serta titik koordinat sebagai berikut $\mathrm{x}=-0.497, \mathrm{y}=$ 26.907, $\mathrm{z}=-42.959$. Penggunaan ukuran grid box dan koordinat yang sama pada saat validasi dilakukan untuk memastikan bahwa senyawa uji ditambatkan secara tepat pada sisi aktif dari tirosinase sesuai dengan hasil validasi.

Luaran hasil dari dilakukannya penambatan adalah berupa score dan pose. Score adalah nilai energi bebas $\left(\Delta \mathrm{G}_{\text {bind }}\right)$ yang mana semakin rendah nilainya menandakan semakin stabil interaksi antara ligan dan resptor sehingga afinitas ligan terhadap reseptor juga menjadi semakin lebih kuat sedangkan pose yaitu konformasi struktur dalam posisi terbaik yang berikatan dengan residu asam amino pada reseptor (Lukitaningsih, et al., 2009). Ikatan yang terjadi antar ligan-reseptor bermacam-macam, akan tetapi ikatan hidrogen sangat diperhatikan karena merupakan ikatan yang paling stabil. Interaksi ikatan hidrogen terjadi antar atom yang tidak terikat secara kovalen satu sama lain pada umumnya merupakan interaksi molekuler yang sering terjadi di dalam tubuh. Adanya ikatan hidrogen menyebabkan aktivitas sifat kimia fisika seperti titik didih, titik lebur, kelarutan dalam air, dan kemampuan pembentukan khelat dapat terpengaruhi. Perubahan tersebut kemudian dapat berpengaruh terhadap aktivitas biologis, seperti penghambatan enzim tirosinase (Suharna, 2012).

Tabel I. Hasil penambatan molekuler senyawa flavonoid daun tabat barito dengan enzim tirosinase

\begin{tabular}{|c|c|c|c|}
\hline \multicolumn{2}{|c|}{ Senyawa } & $\begin{array}{l}\text { Binding affinity } \\
\quad(\text { kcal } / \text { mol })\end{array}$ & $\begin{array}{c}\text { Residu asam amino dengan ikatan } \\
\text { hidrogen }\end{array}$ \\
\hline \multirow[t]{9}{*}{ Uji } & Catechin & -5.78 & $\begin{array}{l}\mathrm{Cu} 400 \text {, Asn 260, His 85, His 296, His } \\
\text { 259, His 61, His } 94\end{array}$ \\
\hline & Vitexin & -5.78 & $\mathrm{Cu} 401, \operatorname{Arg} 268$, Val 283, Ser 282 \\
\hline & Epicatechin & -5.54 & $\begin{array}{l}\mathrm{Cu} 400 \text {, Asn } 260, \text { His } 244, \text { His } 94, \text { His } 61, \\
\text { His } 296 \text {, His } 259\end{array}$ \\
\hline & Orientin & -5.43 & $\mathrm{Cu} 400, \mathrm{Val} 283, \operatorname{Arg} 268$, Ser 282, His 85 \\
\hline & Epiafzelecin & -5.38 & $\mathrm{Cu} 400$, Asn 260, His 244, His 61, His 296 \\
\hline & Gallocatechin & -5.08 & His 244, Asn 260, Gly 281, Arg 268 \\
\hline & Isoschaftoside & -4.91 & $\begin{array}{l}\text { Cys } 83 \text {, His } 85 \text {, His } 244 \text {, Glu } 256 \text {, Asn } \\
\text { 260, Gly } 281\end{array}$ \\
\hline & Epigallocatechin & -4.69 & $\begin{array}{l}\mathrm{Cu} 401, \mathrm{Arg} 268 \text {, Gly } 281 \text {, Glu } 256 \text {, His } \\
244\end{array}$ \\
\hline & Schaftoside & -4.53 & Asn 260, Thr 261, Arg 268, Glu 256, Met \\
\hline
\end{tabular}

Studi Penambatan Molekul Senyawa Flavonoid Daun Tabat Barito... (Alfisyahriatunnida Meily., dkk) 


\begin{tabular}{|c|c|c|c|}
\hline & & & 257 \\
\hline & Isovitexin & -4.08 & Cys 83, Asn 260, Arg 268 \\
\hline & Vicenin & -3.74 & Asn 260, His 244, Ser 282, Thr 261 \\
\hline & $\begin{array}{l}\text { Luteolin-6-C- } \\
\text { glucosyl-8-C- } \\
\text { arabinoside }\end{array}$ & -3.62 & $\begin{array}{l}\text { Ser 282, His 244, Arg 268, Asn 260, Met } \\
\text { 257, Thr } 261\end{array}$ \\
\hline & Lucenin & -3.59 & $\begin{array}{l}\text { Arg 268, Thr 261, Asn 260, His 244, Met } \\
257\end{array}$ \\
\hline Pembanding & Kojic acid & -4.06 & Met 280, Asn 260 \\
\hline Native ligand & Tropolonee & -4.99 & Met 280 \\
\hline
\end{tabular}

Didapatkan 3 senyawa dengan nilai binding affinity terendah yaitu catechin dan vitexin dengan nilai yang sama $-5.78 \mathrm{kcal} / \mathrm{mol}$ dan epicatechin $-5.54 \mathrm{kcal} / \mathrm{mol}$. Selain itu juga terdapat 3 senyawa yang memiliki nilai lebih rendah daripada native ligand yaitu orientin $5.43 \mathrm{kcal} / \mathrm{mol}$, epiafzelecin $-5.38 \mathrm{kcal} / \mathrm{mol}$ dan gallocatechin $-5.08 \mathrm{kcal} / \mathrm{mol}$, yang di mana nilai energi bebas native ligand sendiri yaitu sebesar $-4.99 \mathrm{kcal} / \mathrm{mol}$. Didukung oleh studi terkait senyawa catechin yang diisolasi dari ekstrak etanol dari cabang tumbuhan Distylium racemosum, memiliki nilai $\mathrm{IC}_{50}$ sebesar $30,2 \mathrm{mg} / \mathrm{mL}$ dan menunjukkan aktivitas penghambatan tirosinase yang lebih tinggi daripada Arbutin sebagai kontrol positif (Ko, et al., 2011).

Adapun dari seluruh residu, terdapat 6 residu yang paling banyak berikatan dengan senyawa uji, residu tersebut adalah Asn 260 yang memiliki sebelas ikatan, kemudian Arg 268 sebanyak delapan ikatan, His 244 delapan ikatan, Gly 281, His 85, dan Ser 282 sebanyak empat ikatan. Diperkuat dengan beberapa studi lain tentang penghambatan enzim tirosinase secara in silico, yaitu studi pertama adalah mengenai skrining dan karakterisasi inhibitor tirosinase dari tumbuhan Salvia miltiorrhiza dan Carthamus tinctorius yang dilakukan oleh Wang et al (2018) memperlihatkan adanya interaksi ikatan hidrogen yang terjadi antara ligan dan reseptor pada residu Cys 83, His 85, His 244, Val 283, Ser 282, Gly 281 dan Arg 268 (Wang, et al., 2018). Studi lainnya mempelajari tentang hubungan struktur-aktivitas penghambat tirosinase senyawa Kuwanon G, Mulberrofuran G, dan Albanol B dari Spesies Morus yang dilakukan oleh Koirala, et al., (2018) juga menunjukkan adanya interaksi ikatan hidrogen antar ligan dan reseptor yang terdapat pada residu Arg 268, Asn 260, His 244, Ser 282, Gly 281, Glu 256, Val 283, Cys 83, Met 280, Met 257, Thr 261, dan His 263 (Koirala et al., 2018). Hasil pada studi-studi tersebut analog dengan studi ini, oleh karena itu dapat disimpulkan bahwa flavonoid bekerja sebagai substrat analog yang berinteraksi sebagai inhibitor kompetitif bagi enzim yang mengikat binding site di sekeliling sisi aktif logam $\mathrm{Cu}^{2+}$.

Selain berikatan secara hidrogen dengan residu asam amino yang terletak di sekitar logam $\mathrm{Cu}^{2+}$, terdapat pula beberapa ligan senyawa uji yang juga secara langsung mengikat atom logam $\mathrm{Cu}^{2+}$ yang terdapat pada reseptor dengan ikatan hidrogen yaitu vitexin, catechin, epicatechin, epiafzelechin, epigallocatechin dan orientin. Dalam aktivitas enzim tirosinase, logam $\mathrm{Cu}^{2+}$ memiliki peran penting sebagai kofaktor. Saat logam $\mathrm{Cu}^{2+}$ menghilang dari sisi aktif enzim maka kemampuan katalitik enzim tirosinase mensjadi berkurang, sehingga dopakrom tidak terbentuk (Sagala, et al., 2019). 

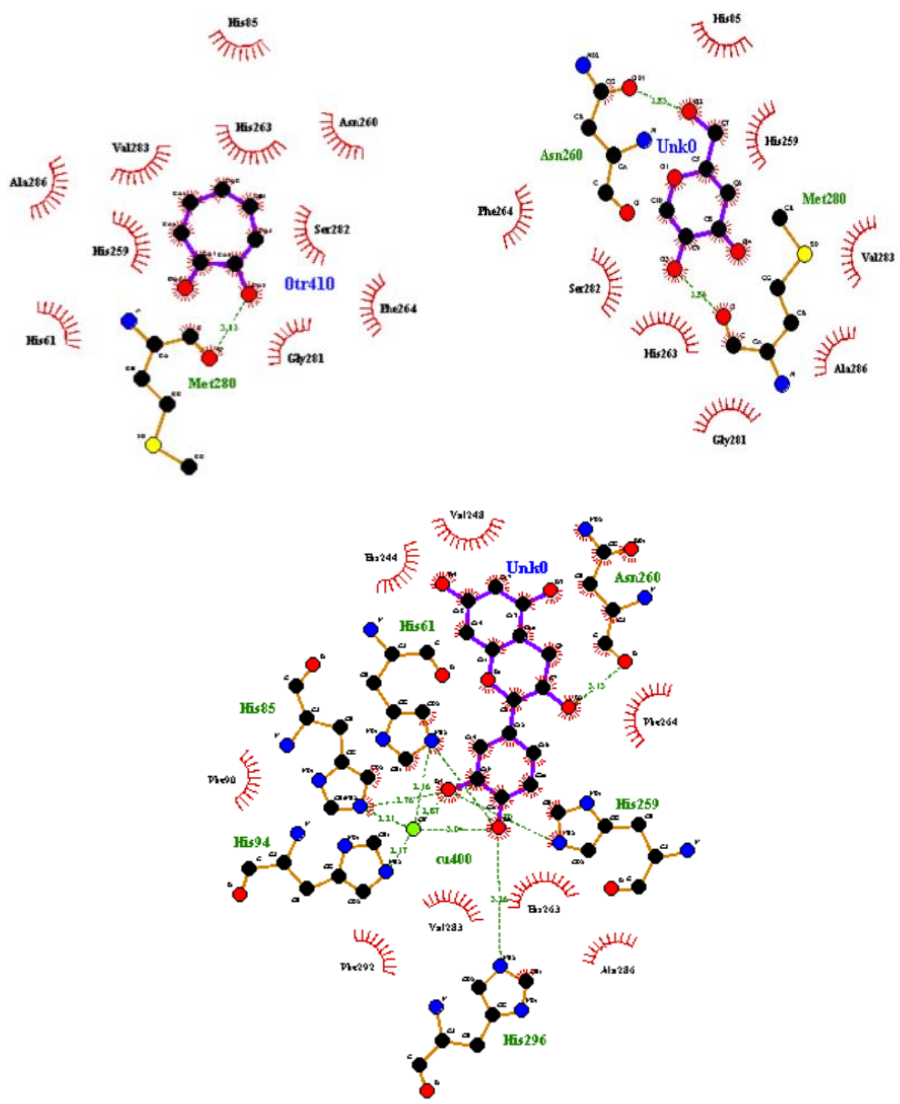

(a)

(b)

(c)

Gambar 2. Interaksi ikatan hidrogen dua dimensi (a) native ligand, (b) senyawa pembanding kojic acid, (c) senyawa uji catechin

Flavonoid merupakan salah satu senyawa fenolik yang dikenal memilki aktivitas sebagai antioksidan, yang dimana antioksidan ini memiliki beragam fungsi dan salah satunya dapat bereaksi sebagai pengkhelat logam. Aktivitas antioksidan pada flavonoid dihasilkan akibat adanya kombinasi reaksi dengan radikal bebas dan pengkhelatan ion logam melalui gugus hidroksil fenolik dalam inti flavonoid, yang terdiri dari cincin A, B dan C (Sugihara, et al., 2001). Pada setiap molekul flavonoid, terdapat tiga domain yang kemungkinan dapat berinteraksi dengan ion logam, yaitu gugus 3',4'-dihidroksi yang terletak pada cincin B, gugus 3-hidroksi atau 5-hidroksi, dan gugus 4 karbonil pada cincin C (Malešev \& Kuntić, 2007). Seperti pada (Gambar 2) dapat dilihat bahwa senyawa catechin berikatan dengan logam $\mathrm{Cu}^{2+}$ pada gugus 3',4'-dihidroksi di cincin B. Adapun pada (Gambar 3) berikut ini adalah visualisasi tiga dimensi ligand pada sisi aktif reseptor secara tiga dimensi.

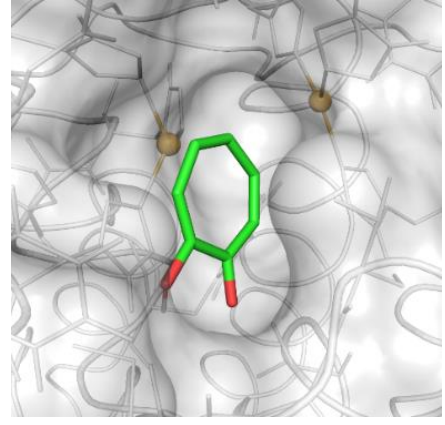

(a)

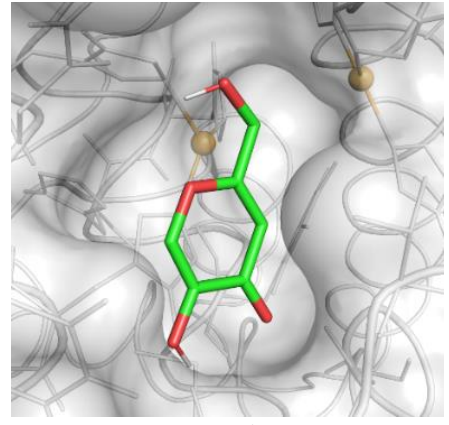

(b)

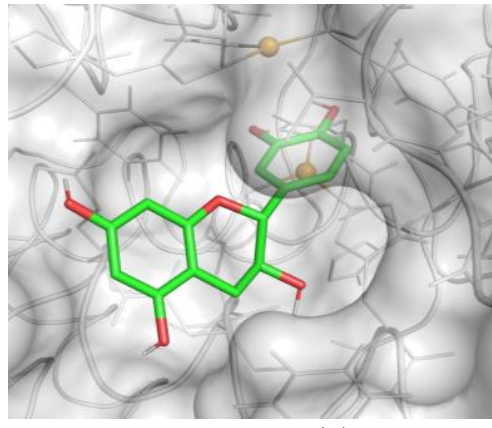

(c) 
Gambar 3. Visualisasi tiga dimensi (a) native ligand, (b) senyawa pembanding kojic acid, (c) senyawa uji catechin

Tabel II. Hasil prediksi karakteristik senyawa

\begin{tabular}{|c|c|c|c|}
\hline \multicolumn{2}{|c|}{ Senyawa } & \multirow{2}{*}{$\begin{array}{c}\log \mathrm{KP} \\
(>-2.5) \\
-2.735\end{array}$} & \multirow{2}{*}{$\begin{array}{c}\begin{array}{r}\text { Sensititas } \\
(Y e s / \mathrm{No})\end{array} \\
\mathrm{No}\end{array}$} \\
\hline Uji & Catechin & & \\
\hline & Vitexin & -2.735 & No \\
\hline & Epicatechin & -2.735 & No \\
\hline & Orientin & -2.735 & No \\
\hline & Epiafzelecin & -2.735 & No \\
\hline & Gallocatechin & -2.735 & No \\
\hline & Isoschaftoside & -2.735 & No \\
\hline & Epigallocatechin & -2.735 & No \\
\hline & Schaftoside & -2.735 & No \\
\hline & Isovitexin & -2.735 & No \\
\hline & Vicenin & -2.735 & No \\
\hline & $\begin{array}{l}\text { Luteolin-6-C- } \\
\text { glucosyl-8-C- } \\
\text { arabinoside }\end{array}$ & -2.735 & No \\
\hline & Lucenin & -2.735 & No \\
\hline Pembanding & Kojic acid & -3.241 & No \\
\hline Native ligand & Tropolone & -2.496 & No \\
\hline
\end{tabular}

Hasil prediksi senyawa uji pada tabel di atas menunjukan bahwa seluruh senyawa aman dan tidak berpotensi menyebabkan sensititas pada kulit. Uji sensititas pada kulit bertujuan untuk mengetahui potensi efek samping pada kulit setelah pemakaian produk apakah senyawa tersebut menimbulkan atau menginduksi efek alergi (Pires, et al., 2015). Sedangkan hasil pengujian untuk permeabilitas kulit dari 15 senyawa didapatkan satu senyawa yang memiliki permeabilitas rendah yaitu senyawa native ligand tropolone. Prediksi permeabilitas kulit melalui situs PkCSM menghasilkan nilai satuan $\operatorname{LogKp}(\mathrm{cm} / \mathrm{h})$, diamana jika nilai permeabilitas kulit memiliki nilai $\operatorname{LogKP}>-2,5$ maka menandakan senyawa tersebut memiliki permeabilitas yang rendah. Permeabilitas pada kulit biasanya digunakan untuk memprediksi suatu senyawa apakah mampu menembus membran kulit untuk kemudian dapat dibuat sediaan transdermal (Pires, et al., 2015). Didukung oleh oleh Yoshino, et al (2012) yang melakukan penelitian terkait pengaruh emulsifikasi pada permeasi kulit dan perlindungan UV dari senyawa golongan catechin mendapatkan hasil bahwa catechin, epicatechin dan epigallocatechin memiliki permeabilitas kulit yang lebih tinggi daripada epicatechingallate dan epigallocatechingallate. Menariknya, permeasi kulit catechin meningkat dengan emulsifikasi o/w (Yoshino, et al., 2013).

\section{KESIMPULAN}

Terdapat beberapa senyawa yang berpotensi menunjukkan penghambatan terbesar terhadap enzim tirosinase dibandingkan dengan native ligand serta senyawa pembanding kojic acid yaitu vitexin $-5.78 \mathrm{kcal} / \mathrm{mol}$, catechin $-5.78 \mathrm{kcal} / \mathrm{mol}$, epicatechin $-5.54 \mathrm{kcal} / \mathrm{mol}$, orientin $5.43 \mathrm{kcal} / \mathrm{mol}$, epiafzelechin $-5.38 \mathrm{kcal} / \mathrm{mol}$ dan gallocatechin $-5.08 \mathrm{kcal} / \mathrm{mol}$. Diperoleh 
residu asam amino pada protein reseptor yang memiliki peran besar dalam pembentukan ikatan hidrogen dengan ligan senyawa uji yaitu Asn 260 yang memiliki sebelas ikatan, kemudian Arg 268 dan His 244 memiliki delapan ikatan, serta Gly 281, His 85, dan Ser 282 memiliki empat ikatan.

\section{DAFTAR_PUSTAKA}

Aji, N. (2019). Potensi Senyawa Aktif Bunga, Kulit Daun dan Getah Aloe Barbadensis Miller. Terhadap Penghambatan Enzim Tyrosinase. Pharmacoscript, 1(1), 109-120. https://doi.org/10.36423/pharmacoscript.v1i1.106

Arifianti, A. E., Anwar Effionora dan, \& Nurjanah. (2017). Aktivitas Penghambatan Tirosinase dan Antioksidan Serbuk Rumput Laut dari Sargassum plagyphyllum Segar dan Kering. Jurnal Pengolahan Hasil Perikanan Indonesia, 20(3), 488-493.

Chang, M. W., Ayeni, C., Breuer, S., \& Torbett, B. E. (2010). Virtual Screening for HIV Protease Inhibitors: A Comparison of Autodock 4 and Vina. PLoS ONE, 5(8), 1-9. https://doi.org/10.1371/journal.pone.0011955

Charissa, M., Djajadisastra, J., \& Elya, B. (2017). Uji Aktivitas Antioksidan dan Penghambatan Tirosinase serta Uji Manfaat Gel Ekstrak Kulit Batang Taya (Nauclea subdita) terhadap Kulit. Jurnal Kefarmasian Indonesia , 6(2), 98-107. https://doi.org/10.22435/jki.v6i2.6224.98-107

Geldenhuys, W. J., Gaasch, K. E., Watson, M., Allen, D. D., \& Schyf, C. J. Van Der. (2006). Optimizing The Use of Open-Source Software Applications in Drug Discovery REVIEWS. 11(3).

Ghafari, S., Fahimi, S., \& Sahranavard, S. (2017). Plants Used to Treat Hyperpigmentation in Iranian Traditional Medicine: A Review. 4(June), 71-85.

Ismaya, W. T., Rozeboom, J., Weijn, A., Mes, J. J., \& Fusetti, F. (2011). Crystal Structure of Agaricus bisporus Tyrosinase. Biochemistry, 50, 5477-5486.

Ko, R. K., Kim, G. O., Hyun, C. G., Jung, D. S., \& Lee, N. H. (2011). Compounds with Tyrosinase Inhibition, Elastase Inhibition and DPPH Radical Scavenging Activities from the Branches of Distylium racemosum Sieb . et Zucc. Phytotherapy Research, 1456(February), 1451-1456.

Koirala, P., Seong, S. H., Zhou, Y., Shrestha, S., Jung, H. A., \& Choi, J. S. (2018). Structure-Activity Relationship of the Tyrosinase Inhibitors Kuwanon G, Mulberrofuran G, and Albanol B from Morus Species: A Kinetics and Molecular Docking Study. https://doi.org/10.3390/molecules23061413

Lukitaningsih, E., Wisnusaputra, A., \& Sudarmanto, B. S. A. (2009). Scrining In Silico Active Compound of Pachyrrhizus erosus as Antitirosinase on Aspergillus oryzae (Computattional Study With Homology Modeling and Molecular Docking). Majalah Obat Tradisional (Traditional Medicine Journal), 20(1), 7-15.

Madhavi Sastry, G., Adzhigirey, M., Day, T., Annabhimoju, R., \& Sherman, W. (2013). Protein and Ligand Preparation: Parameters, Protocols, and Influence on Virtual Screening Enrichments. Journal of Computer-Aided Molecular Design, 27(3), 221234. https://doi.org/10.1007/s10822-013-9644-8

Malešev, D., \& Kuntić, V. (2007). Investigation of metal-flavonoid chelates and the determination of flavonoids via metal-flavonoid complexing reactions. Journal of the Serbian Chemical Society, 72(10), 921-939. https://doi.org/10.2298/JSC0710921M

Nurmaida, N., Darusman, L. K., Rafi, M., \& Heryanto, R. (2018). Metabolite Profiling of Tabat Barito (Ficus deltoidea) Using UPLC-QTOF-MS/MS. The Journal of Pure and Applied Chemistry Research, 7(2), 100-108. https://doi.org/10.21776/ub.jpacr.2018.007.02.374

Oh, M. J., Abdul Hamid, M., Ngadiran, S., Seo, Y. K., Sarmidi, M. R., \& Park, C. S. (2011). Ficus deltoidea ( Mas cotek ) extract exerted anti-melanogenic activity by preventing tyrosinase activity in vitro and by suppressing tyrosinase gene expression in $\mathrm{B} 16 \mathrm{~F} 1$ melanoma cells. 161-170. https://doi.org/10.1007/s00403-010-1089-5

Omar, M. H., Mullen, W., \& Crozier, A. (2011). Identification of Proanthocyanidin Dimers 
and Trimers, Flavone C -Glycosides, and Antioxidants in Ficus deltoidea , a Malaysian Herbal Tea. 1363-1369.

Pires, D. E. V., Blundell, T. L., \& Ascher, D. B. (2015). pkCSM: Predicting Small-Molecule Pharmacokinetic and Toxicity Properties Using Graph-Based Signatures. Journal of Medicinal Chemistry, 58(9), 4066-4072. https://doi.org/10.1021/acs.jmedchem.5b00104

Qian, W., Liu, W., Zhu, D., Cao, Y., Tang, A., Gong, G., \& Su, H. (2020). Natural Skin-Whitening Compounds for The Treatment of Melanogenesis (Review). Experimental and Therapeutic Medicine, 20(1), 173-185. https://doi.org/10.3892/etm.2020.8687

Sagala, Z., Pratiwi, R. W., Azmi, N. U., \& Maap. (2019). Uji Aktivitas Inhibisi terhadap Enzim Tirosinase dari Ekstrak Etanol Daun Pepaya ( Carica papaya L .) Secara In Vitro. Jurnal Penelitian Farmasi Indonesia, 7(2), 34-38.

Silva, A. da, Silva, N., Andrade, E., Gratieri, T., Setzer, W., \& JGS Maia, et al. (2017). Tyrosinase Inhibitory Activity, Molecular Docking Studies and Antioxidant Potential ff Chemotypes Of Lippia Origanoides ( Verbenaceae ) Essential Oils. PLoS ONE, 263, 117. https://doi.org/https://doi.org/ 10.1371/journal.pone.0175598

Sugihara, N., Ohnishi, M., Imamura, M., \& Furuno, K. (2001). Differences in antioxidative efficiency of catechins in various metal-induced lipid peroxidations in cultured hepatocytes. Journal of Health Science, 47(2), 99-106. https://doi.org/10.1248/jhs.47.99

Suharna. (2012). Studi In Silico senyawa turunan flavonoid terhadap penghambatan enzim Tirosinase [Universitas Islam Negeri Alauddin]. https://www.fairportlibrary.org/images/files/RenovationProject/Concept_cost_estimate _accepted_031914.pdf

Wadood, A., Ahmed, N., Shah, L., Ahmad, A., Hassan, H., \& Shams, S. (2013). In-silico drug design: An approach which revolutionarised the drug discovery process. September. https://doi.org/10.13172/2054-4057-1-1-1119

Walters, K. A., \& Roberts, M. S. (2008). Dermatologic , Cosmeceutic , and Cosmetic Development.

Wang, Y., Hu, G., Zhang, Q., Yang, Y., Li, Q., Hu, Y., Chen, H., \& Yang, F. (2018). Screening and Characterizing Tyrosinase Inhibitors from Salvia miltiorrhiza and Carthamus tinctorius by Spectrum-Effect Relationship Analysis and Molecular Docking. 2018.

Widyastuti, M. D., Noviyanti, N. K. M., Sanjaya, I. K. N. S., \& Susanti, N. M. P. (2020). Aktivitas Antihiperpigmentasi Likopen Secara in Silico. Jurnal Kimia, 14(2), 107. https://doi.org/10.24843/jchem.2020.v14.i02.p01

Yanuar, A. (2012). Penambatan Molekular, Praktek dan Aplikasi pada Virtual Screening (1 ed.). Fakultas Farmasi Universitas Indonesia.

Yoshino, S., Mitoma, T., Tsuruta, K., Todo, H., \& Sugibayashi, K. (2013). Effect of emulsification on the skin permeation and UV protection of catechin. 7450, 1-6. https://doi.org/10.3109/10837450.2013.788512

Zuchiran, M. R. (2010). Penambatan molekuler beberapa senyawa xanton dari tanaman garcinia mangostana Linn. pada enzim plasmepsin dan reduktase protein pembawa enoil asil plasmodium falciparum [Universitas Indonesia]. In Skripsi. http://lib.ui.ac.id/detail.jsp?id=20181161 